\title{
Isolation and Characterization of Yeasts from Rumen Fluids for Potential Use as Additives in Ruminant Feeding
}

\author{
Chanon Suntara ${ }^{1}$, Anusorn Cherdthong ${ }^{1, *} \mathbb{C}$, Metha Wanapat ${ }^{1} \mathbb{C}$, Suthipong Uriyapongson ${ }^{1}$, \\ Vichai Leelavatcharamas ${ }^{2}$, Jutaporn Sawaengkaew ${ }^{3}$, Pin Chanjula ${ }^{4}$ and Suban Foiklang ${ }^{5}$ (i) \\ 1 Tropical Feed Resources Research and Development Center (TROFREC), Department of Animal Science, \\ Faculty of Agriculture, Khon Kaen University, Khon Kaen 40002, Thailand; Chanon_su@kkumail.com (C.S.); \\ metha@kku.ac.th (M.W.); suthipng@kku.ac.th (S.U.) \\ 2 Fermentation Research Center for Value Added Agricultural Products (FerVAAP), Department of \\ Biotechnology, Faculty of Technology, Khon Kaen University, Khon Kaen 40002, Thailand; viclee@kku.ac.th \\ 3 Department of Microbiology, Faculty of Science, Khon Kaen University, Khon Kaen 40002, Thailand; \\ sjutap@kku.ac.th \\ 4 Animal Production Innovation and Management Division, Faculty of Natural Resources, Hat Yai Campus, \\ Prince of Songkla University, Songkhla 90112, Thailand; pin.c@psu.ac.th \\ 5 Faculty of Animal Science and Technology, Maejo University, Chiangmai 50290, Thailand; \\ bungung@hotmail.com \\ * Correspondence: anusornc@kku.ac.th; Tel.: +66-43-202362
}

Citation: Suntara, C.; Cherdthong, A.; Wanapat, M.; Uriyapongson, S.; Leelavatcharamas, V.; Sawaengkaew, J.; Chanjula, P.; Foiklang, S. Isolation and Characterization of Yeasts from Rumen Fluids for Potential Use as Additives in Ruminant Feeding. Vet. Sci. 2021, 8, 52. https:// doi.org/10.3390/vetsci8030052

Academic Editor: Enrico Gugliandolo

Received: 9 February 2021

Accepted: 16 March 2021

Published: 19 March 2021

Publisher's Note: MDPI stays neutral with regard to jurisdictional claims in published maps and institutional affiliations.

Copyright: ( $\odot 2021$ by the authors Licensee MDPI, Basel, Switzerland. This article is an open access article distributed under the terms and conditions of the Creative Commons Attribution (CC BY) license (https:// creativecommons.org/licenses/by/ $4.0 /)$.
Abstract: Saccharomyces cerevisiae is a yeast strain often used to improve the feed quality of ruminants. However, S. cerevisiae has limited capacity to provide biomass when inoculated with carbon sources and a low ability to produce cellulase enzymes. Here, we hypothesized that yeast in the rumen produces a large amount of biomass and could release cellulase enzymes to break down fiber content. Therefore, the aim of this study was to screen, isolate and identify yeast from the rumen fluids of Holstein Friesian steers and measure the efficiency of biomass production and cellulase activity. A fermentation medium containing sugarcane molasses as a carbon source and urea as a nitrogen source was optimized. Two fistulated-crossbred Holstein Friesian steers averaging $350 \pm 20 \mathrm{~kg}$ body weight were used to screen and isolate the ruminal yeast. Two experiments were designed: First, a $12 \times 3 \times 3$ factorial was used in a completely randomized design to determine biomass and carboxymethyl cellulase activity. Factor A was the isolated yeast and S. cerevisiae. Factor B was sugarcane molasses (M) concentration. Factor $\mathrm{C}$ was urea $(\mathrm{U})$ concentration. In the second experiment, potential yeasts were selected, identified, and analyzed for $7 \times 4$ factorial use in a completely randomized design. Factor A was the incubation times. Factor B was the isolated yeast strains, including codes H-Khon Kaen University (KKU) 20 (as P. kudriavzevii-KKU20), I-KKU20 (C. tropicalis-KKU20), and C-KKU20 (as Galactomyces sp.-KKU20). Isolation was imposed under aerobic conditions, resulting in a total of 11 different colonies. Two appearances of colonies including asymmetric colonies of isolated yeast (indicated as A, B, C, E, and J) and ovoid colonies (coded as D, F, G, H, I, and K) were noted. Isolated yeast from the rumen capable of providing a high amount of biomass when inoculant consisted of the molasses 15\% + urea 3\% (M15 + U3), molasses 25\% + urea 1\% (M25 + U1), molasses $25 \%$ + urea 3\% (M25 + U3), and molasses 25\% + urea 5\% (M25 + U5) when compared to the other media solution $(p<0.01)$. In addition, 11 isolated biomass-producing yeasts were found in the media solution of M25 + U1. There were 4 isolates cellulase producing yeasts discovered in the media solution of M25 + U1 and M25 + U5 whereas molasses 5\% + urea 1\% (M5 + U1), molasses $5 \%$ + urea 3\% (M5 + U3), molasses 5\% + urea 5\% (M5 + U5), molasses 15\% + urea 1\% (M15 + U1), molasses 15\% + urea 3\% (M5 + U3), and M25 + U3 were found with 2, 3, 1, 2, 1, and 2 isolates, respectively. Ruminal yeast strains H-KKU20, I-KKU20, and C-KKU20 were selected for their ability to produce biomass. Identification of isolates H-KKU20 and I-KKU20 revealed that those isolates belonged to Pichia kudriavzevii-KKU20 and Candida tropicalis-KKU20 while C-KKU20 was identified as Galactomyces sp.-KKU20. Two strains provided maximum cell growth: $P$. kudriavzevii-KKU20 (9.78 and 10.02 Log cell /mL) and C. tropicalis-KKU20 (9.53 and 9.6 Log cells $/ \mathrm{mL}$ ) at 60 and $72 \mathrm{~h}$ of incubation time, respectively. The highest ethanol production was observed in S. cerevisiae at 76.4, 
$77.8,78.5$, and $78.6 \mathrm{~g} / \mathrm{L}$ at $36,48,60$, and $72 \mathrm{~h}$ of incubation time, respectively $(p<0.01)$. The $P$. kudriavzevii-KKU20 yielded the least reducing sugar at about 30.6 and $29.8 \mathrm{~g} / \mathrm{L}$ at 60 and $72 \mathrm{~h}$ of incubation time, respectively. The screening and isolation of yeasts from rumen fluids resulted in 11 different yeasts being obtained. The potential yeasts discovered in the rumen fluid of cattle were Pichia kudriavzevii-KKU20, Candida tropicalis-KKU20, and Galactomyces sp.-KKU20. P. kudriavzeviiKKU20 had higher results than the other yeasts in terms of biomass production, cellulase enzyme activity, and cell number.

Keywords: ruminal yeast; screening; isolation; biomass of yeast; cellulase enzyme

\section{Introduction}

The use of microbial additives such as yeast cultures has recently become common practice in ruminant nutrition [1]. In addition, the introduction of yeasts in the ruminant diet could replace antibiotic use as a growth promoter [2]. Yeast can act as a growth promoter by manipulating the ruminal environment so that it becomes more suitable for microorganisms. Yeast's important roles include oxygen scavenging by reducing the amount of oxygen in the rumen and increasing the survival of other anaerobic microorganisms supplying essential nutrients such as mannooligo saccharide, protein or protein amino acid chelates, vitamins (B-complex), and minerals to other microorganisms upon cell lysis in the rumen; yeast can also stimulate the immune system in the hindgut [3]. These mechanisms affect animals by leading to maximum microbial population in the rumen, which increases their effectiveness in terms of their subsequent productivity [4]. Previous studies have confirmed that supplementation of $S$. cerevisiae as a direct feed can improve animal performance [5]. Other strategies apply S. cerevisiae and enhance feed quality as a feedstuff or as a byproduct by multiplying the yeast in the media solution; here, molasses $(\mathrm{M})$ is the carbon source and urea (U) is the nitrogen source. This can expand the yeast population before treatment [6]. Previous experiments showed that the byproduct can be fermented with yeast for positive effect; its benefits are approximately the same when directly fed to animal [7].

The application of S. cerevisiae to fermented durian hull and ethanol waste (from cassava pulp) could enhance rumen fermentation, increase the ruminal bacteria population, and the average daily gain (ADG) of crossbred Brahman-Thai native cattle [8,9]. In addition, $S$. cerevisiae (plus malic acid) fermented with cassava pulp was suggested as a $50 \%$ replacement for soybean meal (SBM) in a concentrate diet for crossbred Brahman-Thai native beef cattle [10]. This achievement is attributable to the proliferation of the yeast cells and amino acids supply to the animal [9]. In addition, some studies have tried improving rice straw (RS) via fermentation with $S$. cerevisiae.

In Thailand, one of the most abundant by-products is rice straw (RS); it is regularly used as a roughage source for ruminant animals [11]. The nutritional values of RS include crude protein 3-4\% and NDF 70.2\%. The energy level from the total digestible nutrient (TDN) is considered low [12]. Although there are several approaches for improving the quality of RS, increasing protein and fiber digestion are the main pathways to success [12]. To date, there is still little available information about the use of $S$. cerevisiae to improve RS, and most of that research is not focused on RS fiber [13]. S. cerevisiae also may have a limited capacity to provide biomass when inoculated in high-glucose conditions before being used to treat byproducts especially RS.

This phenomenon is supported by Wardrop et al. [14], who stated that $S$. cerevisiae provides seven-fold less biomass than Kluveromyces marxianus when cultured in a media solution with high glucose. This is clearly true for S. cerevisiae due to the high ethanol yield produced. This is because glucose in S. cerevisiae could inhibit PDH and produce ethanol instead [15]. This phenomenon restricts the chances of animals receiving highly 
nutritious components from yeast cells, such as protein, essential amino acids, and vitamins. Therefore, using a different yeast strain may produce interesting and useful results.

The use of ruminal yeast as a feed additive has been studied [16], and yeasts isolated from the rumen appear to be much better for ruminant animals than those from other sources [17]. The capacity to develop biomass or other desirable properties, in particular the production of cellulase enzymes, has not yet been previously studied in rumen-isolated yeast. This is despite past studies suggesting that cellulase can be formed by some strains of yeast [18]. Our motivation here was to avoid the limitations of $S$. cerevisiae and determine the enzyme properties and thus enhance the value of RS.

Before the yeast inoculant can ferment with RS, we need to know the strains of yeast present in the rumen, the conditions for their growth, and their properties. A fermentation medium containing sugarcane molasses as a carbon source and urea as a nitrogen source was modified. We hypothesized that the yeast in the rumen produces a large amount of biomass and could release cellulase enzymes to break down the fiber content. Therefore, our goal was to screen, isolate, and identify yeast from the rumen fluids of Holstein Friesian steers and measure the efficiency of biomass production and cellulase activity.

\section{Materials and Methods}

All procedures involving animals in the metabolism studies were approved by the Institutional Animal Care and Use Committee of Khon Kaen University (KKU) (record no. IACUC-KKU 38/62).

\subsection{Screening and Selection Potential Yeasts in the Rumen}

\subsubsection{Animals, Diet and Isolation Procedure}

The study was conducted at Tropical Feed Resources Research and Development Center (TROFREC), Department of Animal Science, Faculty of Agriculture, Khon Kaen University (KKU), Thailand. Two fistulated-crossbred Holstein Friesian steers, averaging $350 \pm 20 \mathrm{~kg}$ body weight, were used as rumen inocula donors.

Two fistulated dairy steers were held in independent pens and individually fed ad libitum rice straw as roughage and $0.5 \% \mathrm{BW}$ concentrate diets $(16.0 \%$ crude protein $(\mathrm{CP})$ and $75.0 \%$ total digestible nutrient (TDN) according to NRC [19]); they were given clean, fresh water and mineral blocks. The steers were fed at 07:00 a.m. and 04:00 p.m. The diet was calculated to meet animal requirements and with adequate nutrients for support microorganism in the rumen thus allowing this to occur for 7 days before the rumen fluid was obtained. According to Sirisan [20], the ruminal fluid was collected only once on day 7 from each fistulated steer via a rumen cannula $4 \mathrm{~h}$ after the morning feed. Rumen fluids from the two steers were mixed well before being filtered through a cheesecloth folded to form 4 layers. The fluid was filtered into a bottle and placed immediately into an ice bucket $\left(4{ }^{\circ} \mathrm{C}\right)$. Samples were transported to the laboratory within $15 \mathrm{~min}$. In the laboratory, $1 \mathrm{~mL}$ of ruminal fluid from each animal was diluted with $0.85 \%$ sodium chloride to 1:10, 1:100, and 1:1000 for a total plate count. Each ruminal fluid dilution was spread over a yeast-malt extract (YM) agar plate (HiMedia Laboratories Pvt. Ltd., India), which was then incubated at $39{ }^{\circ} \mathrm{C}$ for $72 \mathrm{~h}$. The inoculant plate was dissolved in distilled water and sterilized for $15 \mathrm{~min}$ at $121^{\circ} \mathrm{C}$ via autoclaving. The $\mathrm{YM}$ agar consisted of malt extract $(3 \mathrm{~g} / \mathrm{L})$, yeast extract $(3 \mathrm{~g} / \mathrm{L})$, peptone $(5 \mathrm{~g} / \mathrm{L})$, agar $(20 \mathrm{~g} / \mathrm{L})$, and glucose $(10 \mathrm{~g} / \mathrm{L})$.

\subsubsection{Morphological Characterization}

The streaking method was used to grow yeast colonies on agar media; samples were moved and regrown on another YM agar plate and then incubated for 7 days at room temperature. Yeast colonies were examined under a $40 \times$ light microscope. The isolated yeast strains were identified by studying different morphological characteristics [21]. The appearance of the yeast colonies was recorded: size, shape, convexity, surface, and color of colonies for purification. Colonies growing along the points of the streak were moved, purified, regrown in a YM broth (HiMedia Laboratories Pvt. Ltd., Mumbai, India), and 
kept in the refrigerator at $4{ }^{\circ} \mathrm{C}$ as stock colonies of yeasts. The isolates were then subjected to an initial assessment to determine their biomass and cellulase production ability by inoculating them in different solutions of sugarcane molasses, urea, and carboxymethyl cellulose (CMC).

\subsubsection{Determination of the Biomass and Carboxymethyl Cellulase Activity \\ Experimental Design and Preparation of Media Solution}

The current study was conducted at the Fermentation Research Center for Value Added Agricultural Products (FerVAAP), Department of Biotechnology, Faculty of Technology, Khon Kaen University, Khon Kaen, Thailand, from June 2018 to September 2018.

To assess the growth of isolated yeasts in different conditions, we optimized a fermentation medium containing sugarcane molasses as a carbon source and urea as a nitrogen source to measure the efficiency of biomass production and cellulase activity. A completely randomized trial with a $12 \times 3 \times 3$ factorial design was used, including 12 yeasts (11 isolated from the rumen and one control), 3 sugarcane concentrations (at 50, 100, and $250 \mathrm{~g} / \mathrm{L}$ distilled water), and 3 urea concentrations (at 10, 30, and $50 \mathrm{~g} / \mathrm{L}$ distilled water); two replicates were carried out for each treatment. Fermentation media were prepared by the addition of sugarcane molasses as a carbon source (Khon Kaen Dairy cooperative Co., Ltd., Khon Kaen, Thailand), urea as a nitrogen source (Saengtawee Panit Co., Ltd., Khon Kaen, Thailand), and carboxymethyl cellulose (CMC) $10 \mathrm{~g} / \mathrm{L}$ distilled water as a stimulant substrate (Chemipan Co., Ltd., Bangkok, Thailand).

The media solution was autoclaved at $121{ }^{\circ} \mathrm{C}$ for $15 \mathrm{~min}$ to allow the media solution to cool down to room temperature before the addition of $70 \% \mathrm{H}_{2} \mathrm{SO}_{4}$ to adjust the $\mathrm{pH}$ to 3.5 [10]. The $\mathrm{pH}$ levels of the fermentation media with isolated yeast and that of the sugarcane molasses with urea were measured by a glass electrode $\mathrm{pH}$ meter (Hanna Instruments, Inc., Woonsocket, RI, USA). The media were placed into $250 \mathrm{~mL}$ Erlenmeyer flasks. The flasks were filled to $100 \mathrm{~mL}$, and $1 \mathrm{~mL}$ of isolated homogenous yeast suspension from the rumen (about $10^{6}$ cells per $\mathrm{mL}$ ) was kept in aseptic conditions. Flasks were cotton plugged before incubation in an incubator-shaker machine [22].

Different levels of sugarcane molasses and urea were prepared with $100 \mathrm{~mL}$ of solution in a 250-mL Erlenmeyer flask by adding a single colony from a stock culture of all isolated and $S$. cerevisiae starter cultures $\left(10^{6}\right.$ cells $)$ to the fermentation media. The cultures were then inoculated in an incubator-shaker at $30{ }^{\circ} \mathrm{C}$ and $150 \mathrm{rpm}$ for $72 \mathrm{~h}$. One milliliter of fluid culture was collected in a $1.5 \mathrm{~mL}$ tube with 2 replicates at each treatment condition to measure biomass and cellulase activity. After determination, the optimum conditions for yeast to produce the greatest amount of biomass and cellulase were recorded, and the highest yields of the yeast colonies were also selected for further experiments including cell counts, reducing sugar, and ethanol production.

Biomass was determined as described by Johnson et al. [23]. Here, $1 \mathrm{~mL}$ of cultured liquid sample was centrifuged in a $1.5 \mathrm{~mL}$ tube at room temperature at $10,000 \times g$ for $10 \mathrm{~min}$. After centrifugation, the sample was separated into two parts: The precipitate parts or cell pellets were first washed with distilled water and then dried at $105^{\circ} \mathrm{C}$ until the weight of biomass remained constant. Second, the crude supernatant was collected to measure the activity of carboxymethyl cellulase as determined using the DNS reagent via a colorimetric method according to Miller [14]: Here, $0.5 \mathrm{~mL}$ of crude supernatant was applied to $0.5 \mathrm{~mL}$ of $1 \%(w / v)$ CMC solution. This solution was inserted into $0.05 \mathrm{M}$ citrate phosphate buffer ( $\mathrm{pH} 4.0$ ) and incubated at $45^{\circ} \mathrm{C}$ for $30 \mathrm{~min}$ [15]. The enzymatic reaction was interrupted via the addition of $1.0 \mathrm{~mL}$ DNS reagent and by placing the solution into a boiling water bath for $10 \mathrm{~min}$. A spectrophotometer measured the color of the reaction product as $540 \mathrm{~nm}$. One enzyme unit was defined as the quantity of enzyme that hydrolyzed CMC to produce $1 \mu \mathrm{mol}$ of sugar per minute under experimental conditions. The equation is derived from the glucose-equivalent factor generated in the assay in mmol of glucose, the volume of the enzyme being tested in the assay $(0.5 \mathrm{~mL})$, and the incubation time $(30 \mathrm{~min})$ required for the generation of the reducing equivalents [24]. 
Carboxymethyl cellulase activity $($ Unit $/ \mathrm{mL})=(\mathrm{C} \times \mathrm{D}) \div \mathrm{MTV}$

Then: $\mathrm{C}=$ Releasing glucose from cellulase $(\mathrm{mg})$

$\mathrm{D}=$ Dilution factor of enzyme

$\mu \mathrm{M}=$ Glucose molecular weight $(180 \mu \mathrm{g} / \mu \mathrm{mol})$

$\mathrm{T}=$ Time incubation

$\mathrm{V}=$ Enzyme volume

The purpose of this experiment was to select the appropriate media solution for the yeast to grow with the highest yield biomass and cellulase activity. Only one media solution was selected to expand the population of yeast before fermenting with RS in further experiments. The yeast was selected for three colonies, which are the highest biomass and cellulase producing colonies in the media solution. Therefore, the main consideration is to use the data from two parameters: biomass and cellulase production.

\subsection{Study of Potential Ruminal Yeast and Identification}

\subsubsection{Molecular Identification of Selected Ruminal Yeast}

DNA isolation was performed by boiling lysis buffer cells according to Maniatis and Fritsch's methods [20] with slight modifications. A loopful of yeast cells was transferred to a $1.5 \mathrm{~mL}$ Eppendorf tube and $100 \mu \mathrm{L}$ of lysis buffer was added. The cell suspensions were boiled for $15 \mathrm{~min}$ in a water or metal block bath. After boiling, $100 \mu \mathrm{L}$ of $2.5 \mathrm{M}$ potassium acetate $(\mathrm{pH} 7.5)$ was added and placed on ice for $1 \mathrm{~h}$, then centrifuged for $5 \mathrm{~min}$ at 14,000 rpm. Supernatant was extracted twice with chloroform:isoamyl alcohol (24:1 $v / v$ ). DNA was precipitated with isopropanol, placed on hold for $10 \mathrm{~min}$ at $20^{\circ} \mathrm{C}$, and centrifuged for $15 \mathrm{~min}$ at $15,000 \mathrm{rpm}$. DNA pellets were rinsed with $70 \%$ ethanol and $90 \%$ ethanol, then dried at room temperature for 15-30 min. The dried DNA was dissolved in $30 \mu \mathrm{L}$ Milli-Q purified water.

The divergent D1/D2 domain of 26S rDNA was amplified with primers NL-1 (5'-GCA TAT CAA TAA GCG GAG GAA AAG-3') and NL4 (5'-GGT CCG TGT TTC AAG ACG G-3') [25]. Amplification was performed in $100 \mu \mathrm{L}$ of reaction mixture conditioning $100 \mathrm{ng}$ of $2.5 \mathrm{U}$ of Taq polymerase, genomic DNA, $40 \mathrm{mM}$ of each primer, $20 \mathrm{mM}$ of each dNTP, $1.5 \mathrm{mM} \mathrm{MgCl} 2$, and $10 \mathrm{mM}$ Tris- $\mathrm{HCl}$. The reaction was pre-denatured at $94^{\circ} \mathrm{C}$ for $5 \mathrm{~min}$. This was repeated at $94{ }^{\circ} \mathrm{C}$ for $1 \mathrm{~min}$ for $30 \mathrm{PCR}$ cycles, with annealing at $55^{\circ} \mathrm{C}$ for $1 \mathrm{~min}$, and extension at $72{ }^{\circ} \mathrm{C}$ for $2.5 \mathrm{~min}$, followed by the final extension at $72{ }^{\circ} \mathrm{C}$ for $10 \mathrm{~min}$. According to the manufacturer's instructions, the amplified DNA was purified with a QIAquick PCR purification kit. Visualization of purified amplified DNA was accomplished by electrophoresis using $0.8 \%$ agarose gel in $1 \times$ tris-borate-EDTA (TBE) buffer and staining with ethidium bromide $\left(8 \times 10^{-5} \mu \mathrm{g} / \mathrm{mL}\right)$, observed under a UV illuminator.

The nucleotide sequences of the 26S rDNA D1/D2 domain were determined directly using PCR products according to Kurtzman and Robnett [25], with slight modifications. Cycle sequencing of the D1/D2 domain was carried out with the forward primer NL1 (5'GCA TAT CAA TAA GCG GAG GAA AAG-3' $\left.{ }^{\prime}\right)$ and reverse primer, NL4 (5'-GGT CCG TGT TTC AAG ACG G-3'), using an ABI PrismTM BigDye ${ }^{\mathrm{TM}}$ Terminator Cycle Sequence Ready Reaction Kit (Applied Biosystems, Stafford, Texas, USA) according to the manufacturer's instructions.

\subsubsection{Measurement of Yeast Cell Growth, Reducing Sugar and Ethanol Production}

Potential yeasts were selected, identified, and analyzed in a $7 \times 4$ factorial use in a completely randomized design with three replications. Factor A was incubation time at 0 , $12,24,36,48,60$, and $72 \mathrm{~h}$. Factor B was isolated yeast strains including codes H-KKU20 (as P. kudriavzevii-KKU20), I-KKU20 (C. tropicalis-KKU20), C-KKU20 (as Galactomyces sp.KKU20), and S. cerevisiae. The optimized fermentation of the media was carried out following the appropriate solutions for potential yeast, biomass, and CMCase activity. The samples were collected in six $1.5 \mathrm{~mL}$ tubes with duplicates (two tubes each for cell count, reducing sugars, and ethanol production) for each incubation time at $0,12,24,36$, 48,60 , and $72 \mathrm{~h}$. In the first two tubes, fresh samples were monitored immediately via 
the counting method using a hemocytometer under a microscope according to Darvishi et al. [26].

Another two tubes determined the reducing sugars using the 3,5-dinitrosalicylic acid (DNS) method [27]. A double-beam UV scanning spectrophotometer was used to measure absorbance. A reduction in sugar content before and after fermentation was determined by applying $1.0 \mathrm{~mL}$ of diluted solution ( $1 \mathrm{~mL}$ sample in $9 \mathrm{~mL}$ distilled water) to a test tube with $1.0 \mathrm{~mL}$ of DNS reagent. A blank was run in parallel with $1.0 \mathrm{~mL}$ of distilled water and $1.0 \mathrm{~mL}$ of DNS. The tubes were heated for $15 \mathrm{~min}$ in a bath of boiling water. Next, $5 \mathrm{~mL}$ of distilled water was applied after the tubes were cooled at room temperature, and absorbance values were noted at $540 \mathrm{~nm}$. A reduction in the sugar concentration was determined from the standard glucose curve and via the dilution factors [28].

The last two tubes were centrifuged at 16,000 rpm for $15 \mathrm{~min}$, and the liquid above the solid residue was filtered using a 0.45-micron syringe filter. Ethanol analyses were performed using an Agilent 7890B gas chromatograph (Agilent Corporation, Santa Clara, CA, USA). The standard water-based ethanol solutions were prepared from $0.0-1.0 \%$ $(v / v)$, and 1-2 $\mu \mathrm{L}$ were injected into the gas chromatography (GC) injection port and then subjected to quantitative ethanol analysis using an HP-5 capillary column (length $30 \mathrm{~m}$ ) on a GC apparatus (oven temperature $40{ }^{\circ} \mathrm{C}$; constant flow mode with a Flame Ionization Detector (FID) $300^{\circ} \mathrm{C}$, air flow of $350 \mathrm{~mL} / \mathrm{min}$; inlet temperature of $150{ }^{\circ} \mathrm{C}$ ) [29].

\subsection{Statistical Analysis}

\subsubsection{Dry Biomass and Carboxymethyl Cellulase Activity}

Data for isolated yeast from rumen with different sugarcane molasses and urea concentrations were analyzed as a $12 \times 3 \times 3$ factorial in a completely randomized design. The analysis of variance procedure of the SAS program was used for the analysis and the statistical model is as follows:

$$
Y_{i j k}=\mu+A_{i}+B_{j}+A B_{i j}+C_{k}+A C_{i k}+B C_{j k}+A B C_{i j k}+\varepsilon_{i j k}
$$

where $Y_{i j k}=$ observation, $\mu=$ overall mean, $A_{i}=$ Yeast strain effect $(\mathrm{i}=\mathrm{a}, \mathrm{b}, \mathrm{c}, \mathrm{d}, \mathrm{e}, \mathrm{f}, \mathrm{g}, \mathrm{h}, \mathrm{i}, \mathrm{j}, \mathrm{k}$ and $S$. cerevisiae), $B_{j}=$ sugarcane molasses effect $(\mathrm{j}=5,15$ and $25 \%), A B_{i j}=$ yeast strain effect $\times$ sugarcane molasses effect, $C_{k}=$ urea effect $(\mathrm{k}=1,3$ and $5 \%), A C_{i k}=$ yeast strain effect $\times$ urea effect, $B C_{j k}=$ sugarcane molasses effect $\times$ urea effect, $A B C_{i j k}=$ yeast strain effect $\times$ sugarcane molasses $\times$ urea effect and $\varepsilon_{i j k}=$ error.

\subsubsection{Cell Counts, Ethanol Production and Reducing Sugar}

Data for isolated yeast strains and incubation time were analyzed as a $7 \times 4$ factorial in a completely randomized design. The ANOVA procedure of the SAS program was used for the analysis and the statistical model is as follows:

$$
Y_{i j}=\mu+A_{i}+B_{j}+A B_{i j}
$$

where $Y_{i j k}=$ observation, $\mu=$ overall mean, $A_{i}=$ Incubation time effect $(\mathrm{i}=0,12,24,36$, 48, 60 and $72 \mathrm{~h}$ ), $B_{j}=$ different yeast strains effect ( $\mathrm{j}=\mathrm{H}-\mathrm{KKU} 20$ (as P. kudriavzevii-KKU20), I-KKU20 (as C. tropicalis-KKU20), C-KKU20 (as Galactomyces sp.-KKU20) and S. cerevisiae, $A B_{i j}=$ incubation time effect $\times$ isolated yeast strains effect and $\varepsilon_{i j k}=$ error.

Treatment means were calculated using the Least Square Means (LSMEANS) option of SAS The entire experimental design used ANOVA and the General Linear Model (GLM) procedures of SAS [30] (Version 6.0; SAS Institute Inc., Cary, NC, USA). When F-tests were significant, single-degree-of-freedom orthogonal polynomials were used to determine the trends of factors. The mean treatment differences were determined by Duncan's New Multiple Range Test (DMRT) at $p=0.05$ [31]. 


\section{Results}

\subsection{Isolation and Morphological Characteristics of Yeast Isolated from Rumen Fluids}

Isolation was imposed under aerobic conditions resulting in 11 different colonies whose morphological and microscopic observations are shown in Table 1. The 11 isolates of yeast were grown on YM agar plates and selected for their formed appearance, elevation, colony nature, and colony color. The budding stage of the isolated yeast was observed under a $40 \times$ microscope; the colonies were confirmed to be yeast as shown in Table 1 . Two appearances of colonies were noted including asymmetric colonies of isolated yeast (indicated as A, B, C, E, and J) and ovoid colonies (coded as D, F, G, H, I, and K). In addition, elevations of colonies are indicated as A and B whereas flat colonies are coded as C, D, E, I, and J; convex colonies are indicated as F, G, H, and K. Smooth colonies are coded as D, E, I, and $\mathrm{J}$ while other codes correspond to rough colonies. Most colonies in this study were white except codes D and J, which were colorless. Code G was turbid.

Table 1. Colonies morphology of ruminal yeast strains of Thai-Holstein-Friesian.

\begin{tabular}{|c|c|c|c|c|c|}
\hline Code Name & Picture & Appearance & Elevation & Colony Nature & Colony Color \\
\hline A-KKU20 & & Asymmetrical & Raised & Rough & White \\
\hline B-KKU20 & & Asymmetrical & Raised & Rough & White \\
\hline C-KKU20 & & Asymmetrical & Flat & Rough & White \\
\hline D-KKU20 & & Ovoid & Flat & Smooth and shiny & colorless \\
\hline E-KKU20 & & Asymmetrical & Flat & Rough & White \\
\hline F-KKU20 & & Ovoid & Convex & Smooth & White \\
\hline G-KKU20 & & Ovoid & Convex & Rough & Turbid \\
\hline H-KKU20 & & Ovoid & Convex & Rough & White \\
\hline I-KKU20 & & Ovoid & Flat & Smooth & White \\
\hline J-KKU20 & & Asymetrical & Flat & Smooth & Colorless \\
\hline K-KKU20 & & Ovoid & Convex & Rough & White \\
\hline
\end{tabular}




\subsection{The Biomass Production and Cellulase Activity}

3.2.1. Effects of Varying Concentrations of Sugarcane Molasses and Urea on Biomass of Isolated Yeast at $72 \mathrm{~h}$ of Incubation Time

Interactions were observed between yeast strains and sugarcane molasses with urea on biomass production (Figure 1). Dry biomass production from ruminal isolated yeast was observed from 3.19 to $17.08 \mathrm{~g} / \mathrm{L}$ in all media solutions.

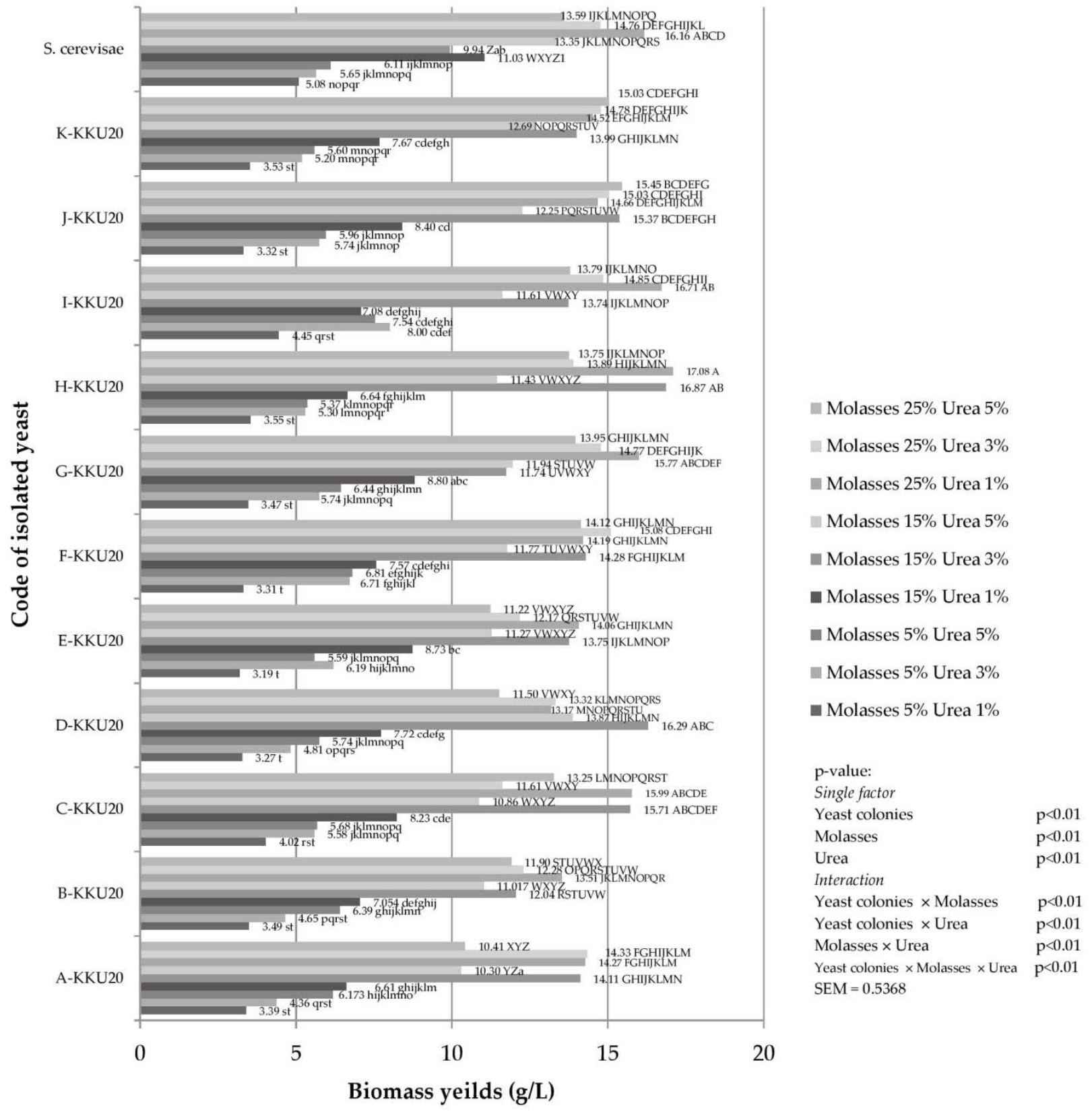

Figure 1. Biomass (horizontal axis) for yeast strains grown in different sugarcane molasses (5, 15 and 25\%) with urea (1, 3 and $5 \%$ ) for $72 \mathrm{~h} .{ }^{\mathrm{A}-\mathrm{Z}, \mathrm{a}-\mathrm{t}}$ Means with different superscript letters within bar chart are considered statistically significant $(p<0.01)$, SEM = standard error of the mean, S. cerevisiae = Saccharomyce cerevisiae.

Isolated yeast from the rumen could provide a high amount of biomass relative to the other media solution $(p<0.01)$ when the inoculant consisted of M15 + U3, M25 + U1, $\mathrm{M} 25+\mathrm{U} 3$, and M25 + U5. In addition, 11 isolates of biomass-producing yeasts were found with a media solution of M25 + U1 whereas M15 + U3, M25 + U3, and M25 + U5 were found by 8,7 , and 2 isolates, respectively. 
3.2.2. Effects of Varying Concentrations of Sugarcane Molasses and Urea on Cellulase Activity of Isolated Yeast at $72 \mathrm{~h}$ of Incubation Time

Interactions were observed between yeast strains and sugarcane molasses with urea in terms of carboxymethyl cellulase activity (Figure 2). Isolated yeast from the rumen could provide a high amount of CMCase when inoculated in all media solutions except M15 + U5 $(p<0.01)$. There were four isolates of cellulase-producing yeasts discovered in the media solution of M25 + U1 and M25 + U5, whereas M5 + U1, M5 + U3, M5 + U5, M15 + U1, $\mathrm{M} 5+\mathrm{U} 3$, and M25 + U3 were found with 2, 3, 1, 2, 1, and 2 isolates, respectively.

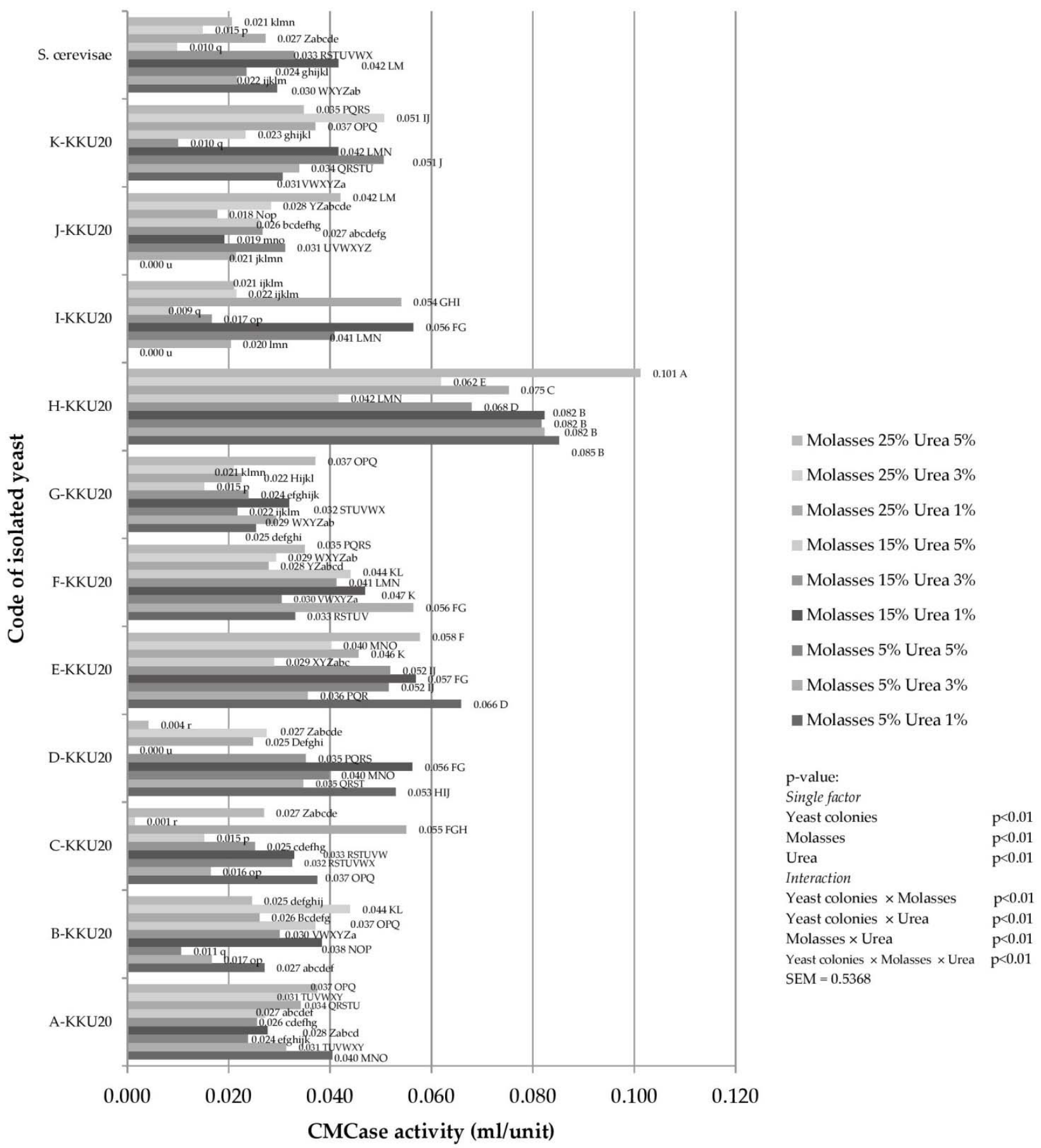

Figure 2. Effect of CMC concentration from $1 \%(w / v)$ on cellulase production of each rumen fluids isolates yeast at 72 h. A-Z,a-u Means with different superscript letters within a bar chart are considered statistically significant $(p<0.01)$, $\mathrm{SEM}=$ standard error of the mean, S. cerevisiae $=$ Saccharomyce cerevisiae. 


\subsection{Selection and Identification of Potential Yeast Strains}

Based on these criteria, only one media solution was selected to expand the population of the yeast before fermenting with RS. We selected M25 + U1 because it has the best potential and expands more than other media solution groups. The top three isolated yeasts from the media solution of M25 + U1 include H-KKU20, I-KKU20, and C-KKU20; these were chosen after considering the CMCase activity. M25 + U1 is a media solution with the same potential for yeast release of CMCase as M25 + U5. However, consideration along with biomass production makes M25 + U1 stand out. It is better than M25 + U5 because it requires a low $\mathrm{N}$ source to produce CMCase. Furthermore, H-KKU20 does not provide the best $\mathrm{CMCase}$ relative to $\mathrm{M} 25+\mathrm{U} 1$ group, but it is the highest. Therefore, these yeast isolates (H-, I-, and C-KKU20) were used for further evaluation.

The newly isolated yeast strain was identified via DNA sequencing [25] using the 26S rRNA gene D1/D2 domain. Identification of isolates H-KKU20 and I-KKU20 revealed that those isolates belonged to Pichia kudriavzevii-KKU20 and Candida tropicalis-KKU20. The D1/D2 sequence of C-KKU20 had 99.82\% (1 nucleotide substitution) similarity with the undescribed species Galactomyces sp. HN21-4 (EU651849) (name changes: Geotrichum sp. HN21-4) and was closest to the Galactomyces geotrichum strain NRRL Y-17569T (NG_054826) but with 11 nucleotide substitutions and one gap. Strain C-KKU20 was identified as Galactomyces sp.-KKU20 (Table 2) based on the sequence of the D1/D2 region.

Table 2. Identification of isolated yeast from rumen fluids.

\begin{tabular}{ccccc}
\hline Isolates & $\begin{array}{c}\text { Gene Bank } \\
\text { Accession No. }\end{array}$ & $\begin{array}{c}\text { Nearest Species } \\
\text { with Accession No. }\end{array}$ & $\begin{array}{c}\text { Nucleotide } \\
\text { Identity (\%) }\end{array}$ & $\begin{array}{c}\text { No. of Nucleotide } \\
\text { Differences }\end{array}$ \\
\hline H-KKU20 & MH545928 & Pichia kudriavzevii & $572 / 572(100)$ & 0 \\
I-KKU20 & U45749 & Candida tropicalis & $570 / 570100$ & 0 \\
C-KKU20 & EU651849 & Galactomyce spp. & $552 / 553(99.82)$ & 1 \\
\hline
\end{tabular}

\subsection{Cell Counts, Ethanol Production and Reducing Sugar by Ruminal Yeast Strains}

\subsubsection{Effect of Incubation Time and Isolated Yeast Strains on Cell Counts}

The influences of various times and yeast strains on cell count are illustrated in Figure 3. There were no interactions between time and yeast in terms of cell count $(p>0.05)$. Yeast cells were counted from 6.24 to $10.02 \mathrm{Log}$ cells $/ \mathrm{mL}$ from over 0 to $72 \mathrm{~h}$ of incubation time. P. kudriavzevii-KKU20 provided the maximum cell growth at $10.02 \mathrm{Log}$ cell $/ \mathrm{mL}$ at 72 $\mathrm{h}$, whereas $S$. cerevisiae showed the lowest cell growth at $8.87 \mathrm{Log}$ cell $/ \mathrm{mL}$ at $72 \mathrm{~h}(p<0.05)$. Yeast-viable cells increased along with incubation time. Maximum cell growth occurred at 60 and $72 \mathrm{~h}$ after incubation $(p<0.01)$. It is possible to proliferate the yeast count cycle in just $60 \mathrm{~h}$.

\subsubsection{Effect of Incubation Time and Isolated Yeast Strains on Ethanol Production}

Galactomyces sp.-KKU20, C. tropicalis-KKU20, S. cerevisiae, and P. kudriavzevii-KKU20 were evaluated for ethanol production, as shown in Figure 4. Interactions were observed between incubation time and isolated yeast strains $(p<0.01)$. The isolated yeast strains produced about 9.76 to $78.6 \mathrm{~g} / \mathrm{L}$ ethanol at 0 to $72 \mathrm{~h}$ of incubation time. The largest amount of ethanol production was observed in S. cerevisiae: $76.4,77.8,78.5$, and $78.6 \mathrm{~g} / \mathrm{L}$ at 36 , 48,60 , and $72 \mathrm{~h}$ of incubation time, respectively $(p<0.01)$. P. kudriavzevii-KKU20 and C. tropicalis -KKU20 produced the least amount of ethanol: 32.9, 37.4, 44.4, and $44.2 \mathrm{~g} / \mathrm{L}$ and $37.3,39.3,44.9$, and $48.5 \mathrm{~g} / \mathrm{L}$ at $36,48,60$, and $72 \mathrm{~h}$ of incubation time, respectively $(p<0.01)$. 


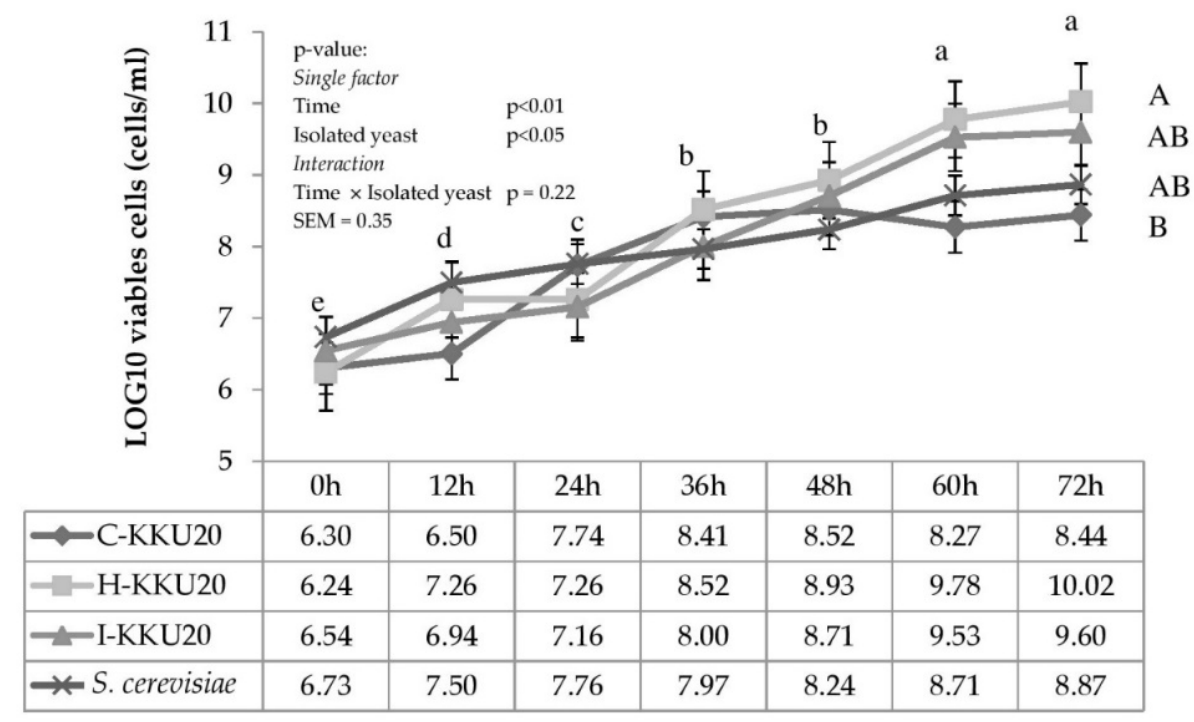

Figure 3. Viable cell count from batch fermentation under sugarcane molasses $25 \%$ with urea $1 \%$ plus $1 \% \mathrm{CMCase}$ in the incubator shaker at $30{ }^{\circ} \mathrm{C}$ and $150 \mathrm{rpm}$ for $72 \mathrm{~h} .{ }^{\mathrm{A}, \mathrm{B}}$ Means with different superscript letters for the effect of yeast colonies are significant at $p<0.05$, ${ }^{\text {a-e }}$ Means with different superscript letters for the effect of time are significant at $p<0.01$. SEM $=$ standard error of the mean, S. cerevisiae $=$ Saccharomyce cerevisiae .

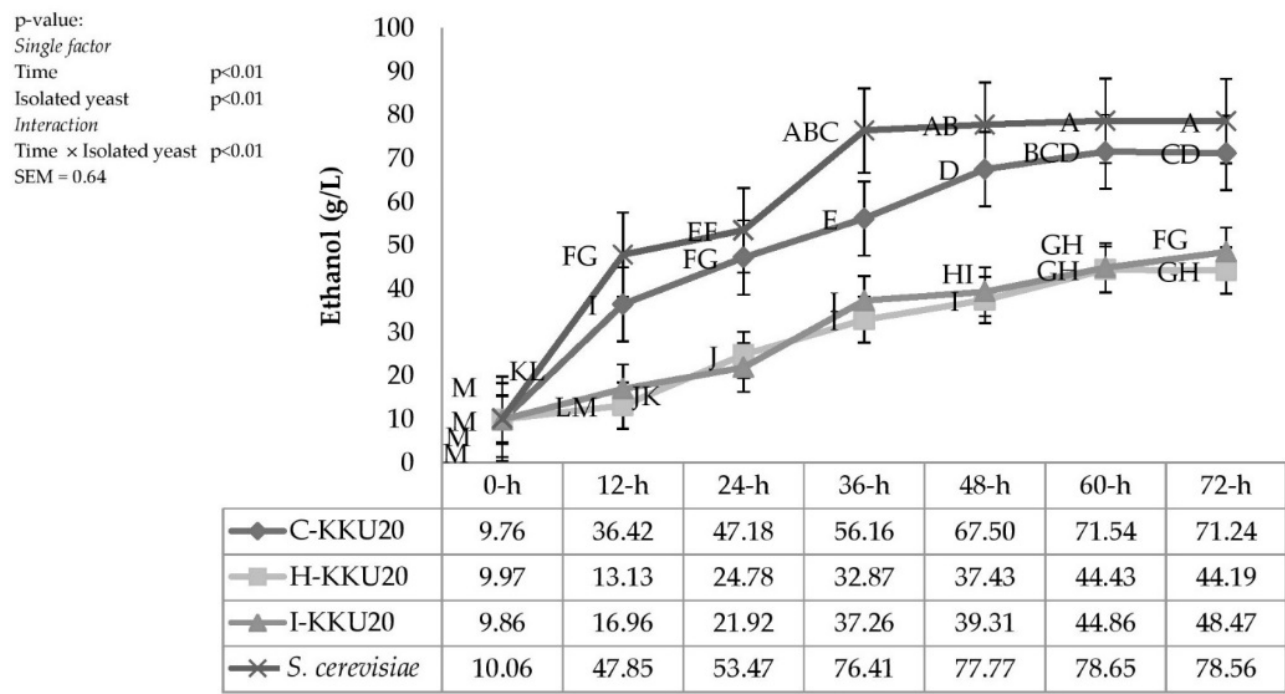

Figure 4. The production of ethanol by four different yeast strains under sugarcane molasses $25 \%$ with urea $1 \%$ plus $1 \% \mathrm{CMC}$ in the incubator shaker at $30^{\circ} \mathrm{C}$ and $150 \mathrm{rpm}$ for $72 \mathrm{~h}$. ${ }^{\mathrm{A}-\mathrm{M}}$ Means with different superscript letters for the interaction effect of time $\times$ yeast colonies are significant at $p<0.01$. SEM = standard error of the mean, S. cerevisiae $=$ Saccharomyce cerevisiae .

\subsubsection{Effect of Incubation Time and Isolated Yeast Strains on Reducing Sugar}

Interaction effects were observed between incubation time and isolated yeast strains $(p>0.05)$ in terms of reducing sugar (Figure 5). The isolated yeast yielded reduction of sugars by between 162.9 and $29.8 \mathrm{~g}$ / L from 0 to $72 \mathrm{~h}$ of incubation time. P. kudriavzeviiKKU20 yielded the lowest amount of reduction in sugar, at about 30.6 and $29.8 \mathrm{~g} / \mathrm{L}$ at 60 and $72 \mathrm{~h}$ of incubation time, respectively. Meanwhile, the two strains that yielded the greatest reduction in sugar were Galactomyces sp.-KKU20 and S. cerevisiae at 60 and $72 \mathrm{~h}$ of incubation time, respectively. 


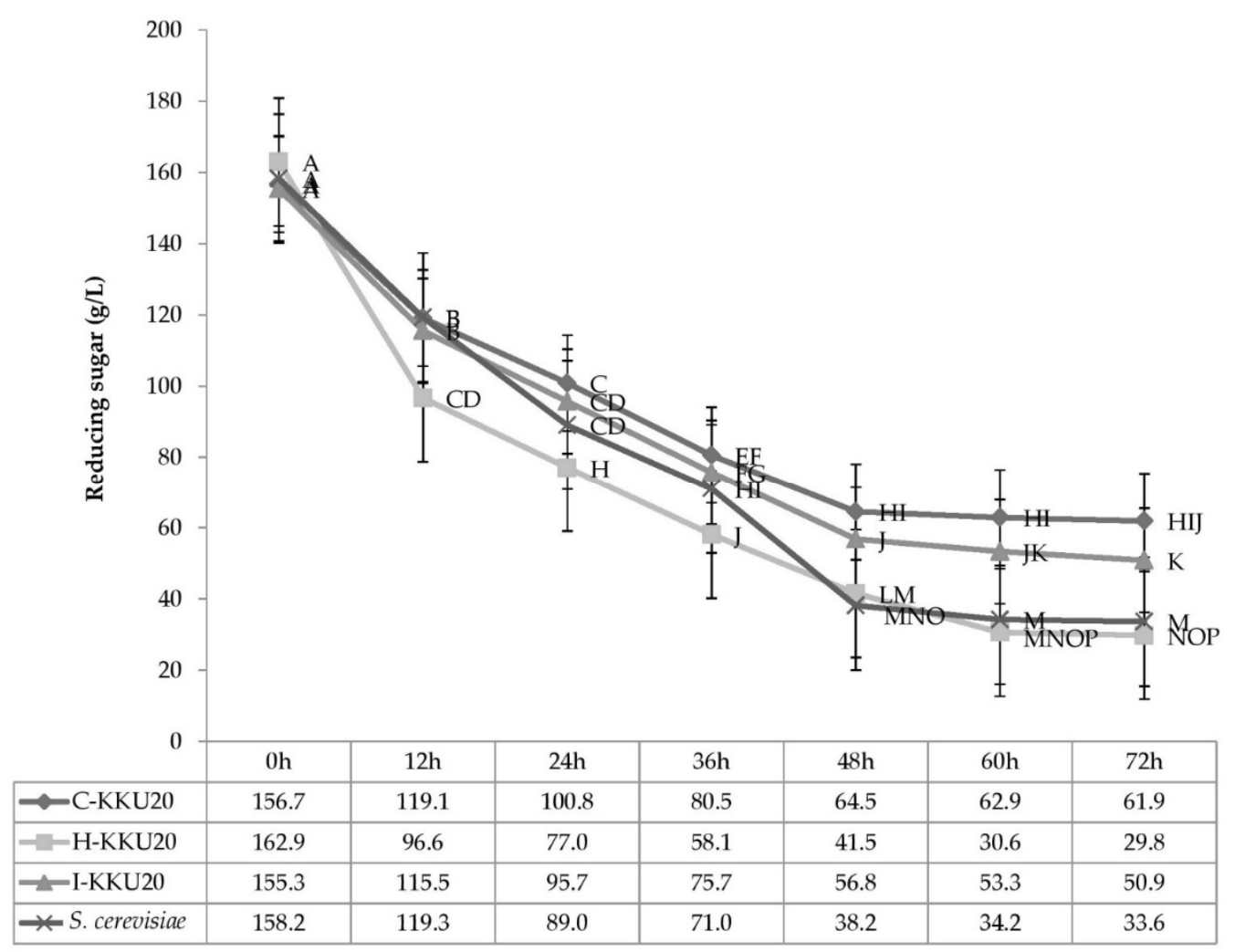

Figure 5. Sugar use by four different yeast strains under sugarcane molasses $25 \%$ with urea $1 \%$ plus $1 \%$ CMC in the incubator shaker at $30^{\circ} \mathrm{C}$ and $150 \mathrm{rpm}$ for $72 \mathrm{~h}$. A-P Means with different superscript letters for the interaction effect of time $\times$ yeast colonies are significant at $p<0.01 . \mathrm{SEM}=$ standard error of the mean, S. cerevisiae $=$ Saccharomyce cerevisiae.

\section{Discussion}

\subsection{Isolation of Yeast from Rumen Fluids}

Yeast isolates were ovoid (6 in 11), flat (5 in 11), convex (4 in 11), or rough (7 in 11). White colonies (9 in 11) appeared most frequently. Yeast was detected similarly to Marrero et al. [32], who concluded that the yeast morphologies in their study were slightly convex, smooth, and white- to cream-colored, which is typical of ruminal yeast. However, many factors might cause different types of yeast to be discovered such as feed sources, roughage per concentrate ratios (R:C), and ruminant species. Marrero et al. [33] isolated yeast from dairy cattle and found that some isolated yeasts could present a pink coloration, which was later discovered to be Levica strains 18 (L18). Thus, the morphological characteristics of ruminal yeast colonies can be quite complex.

\subsection{The Biomass Production and Cellulase Enzyme Activity of Isolated Yeasts}

To increase the biomass of yeast, a substrate such as soluble carbohydrate and nitrogen must provide sufficient supplies for the growth of yeast cells [34]. Paserakung et al. [35] reported that increasing the molasses concentration from $8 \%$ to $16 \%$ resulted in the greatest biomass production of $25.9 \%$ as obtained from Trichosporon asahii. In addition, Johnson, Singh, Saini, Adhikari, Sista, and Yadav [23] studied the effects of different single-substrate carbon sources such as molasses, glucose, and sucrose with limited nitrogen sources in media solutions on the biomass production of Rhodotorula glutinis IIP-30. They found that biomass production increased by $87.8 \%$ in the molasses treatment. Thus, molasses might be a better potential carbon source for Trichosporon asahii growth than other carbon sources [6]. Our media solution contained $25 \%$ molasses with $1 \%$ urea providing a maximum ruminal yeast biomass of $29.2 \%$. This signifies that providing optimum levels of molasses and urea could positively affect biomass production. However, only molasses was used as carbon source in these experiments; thus, another carbon source should be elucidated. 
Manikandan and Viruthagiri [36] reported that the nitrogen source, concentration of nitrogen, and carbon/nitrogen ratio (C:N ratio) also influenced the production of biomass. Danesi et al. [37] demonstrated that the use of sugarcane blackstrap molasses and yeast extract at a C:N ratio of 10:1 provided the greatest biomass from the yeast. In addition, Sokchea et al. [38] found that the biomass of yeast was highest at $7.57 \mathrm{~g} / \mathrm{L}$ when the C:N ratio reached 10:1. Compared to our study, however, the $C: N$ ratio was 25:1, and this high carbon source might lead to a higher level of biomass production $(17.07 \mathrm{~g} / \mathrm{L})$. Proper proportions of carbon and nitrogen can increase yeast growth as in previous experiments where live yeast inoculant was introduced into molasses and urea could increase yeast count and increase animal growth. Boonnop, Wanapat, Nontaso, and Wanapat [6] reported that protein increased from $3.4 \%$ to $32.5 \%$ in cassava chips (93.5\% is true protein) after the yeast proliferated; lysine increased from $3.8 \%$ to $8.5 \%$. While experimenting with cassava root, Khampa, Chuelong, Kosonkittiumporn and Khejornsart [7] found that the effect of yeast fermentation increased the amount of protein in cassava chips by up to $36.1 \%$. However, Khampa et al. [39] showed that the resulting protein component in cassava chips only increased by $19.2 \%$.

Here, the isolated yeast produced and released cellulase enzymes ranging from 0.020 to 0.075 units $/ \mathrm{mL}$. This is the first time that this result has been achieved, which might support the breaking down of fiber content in the rumen. Although studies on the release of cellulase enzymes by yeast from the rumen have not yet been conducted, isolated yeasts from natural sources have demonstrated that yeast could produce cellulase enzymes. Sarawan [22] revealed that Candida glabrata, Candida natalensis, and Kluyveromyces africanus (isolated the from Jasminum adenophyllum plant) can release cellulase enzymes ranging from 0.004 to 0.08 units $/ \mathrm{mL}$ when cultured in yeast extract peptone dextrose broth with $1 \%$ CMC. Thus, cellulase enzymes produced by yeasts might be a potential digest feed due to their cellulose content. Mechanistically, cellulose is hydrolyzed by cellulase as it breaks down the $\beta$-1,4-glycosidic bonds [40]. Cellobiohydrolases (CBHs, EC 3.2.1.91) are important cellulase enzymes found in yeast and are instrumental in high-performance natural cellulose hydrolysis [41]. Examples of $\mathrm{CBH}$ expressed in yeasts include $\mathrm{CBH} 1$ (Cel7A) and CBH2 (Cel6A) [42].

\subsection{Identification of Isolated Yeasts}

Our study isolated three yeasts from rumen fluids: P. kudriavzevii-KKU20, C. tropicalisKKU20, and Galactomyces sp.-KKU20. The name KKU refers to Khon Kaen University where the strain was originally isolated, and the number " 20 " means the year of discovery, 2020. Interestingly, similar yeast species (P. kudriavzevii, C. tropicalis, and Galactomyces sp.) have previously been isolated [43-46]. However, the qualities of these strains have not been studied, and this is the first report on their characteristics such as biomass production, cellulase activity, growth patterns, ethanol production, and the reducing sugars of the yeast from rumen. In addition, the types of potential yeast were Crabtree-negative. Crabtreenegative yeasts $P$. kudriavzevii-KKU20 and C. tropicalis-KKU20 can more rapidly convert available sources of carbon into a solution for yeast biomass. This trend led to consideration of ruminant nutrition as a candidate for the development of protein sources in feed.

\subsection{Cell Counts, Ethanol Production and Sugar Reduction of Selected Ruminal Yeasts}

Our results showed that the Pichia kudriavzevii-KKU20 inoculants in media solution show increased growth versus other species. The maximum yeast growth was $10.02 \mathrm{Log}$ cells / $\mathrm{mL}$ in aerobic conditions at $72 \mathrm{~h}$ of incubation. Pichia kudriavzevii-KKU20 was classified as a Crabtree-negative group; the ability to propagate cells is greater than for the Crabtree-positive group because the glucose use is high. Crabtree-negative yeasts can transport glucose by an inducible high-affinity proton symport mechanism. Aerobic conditions provide especially steady growth conditions [47].

These results clearly indicate that $S$. cerevisiae can produce alcohol when used as an inoculant with a high concentration of carbon under aerobic conditions. Under aerobic 
conditions, S. cerevisiae produced $78.6 \mathrm{~g} / \mathrm{L}$ of ethanol after $72 \mathrm{~h}$, which was more than other species produced. The high ethanol production capability of $S$. cerevisiae occurs because the pyruvate dehydrogenase complex enzyme is inhibited when its inoculant in media solution contained a large amount of sugar [48]; pyruvate decarboxylase is activated instead (three- to four-fold) and changes sugar to ethanol (although there is sufficient oxygen) [49]. Here, the high level of molasses (25\% under aerobic conditions) could also have allowed $S$. cerevisiae to produce a higher ethanol concentration versus other yeast species.

The sugar consumption by yeasts is related to their growth curve and depends on the yeast species [50]. Isolated yeast strains from rumen have a higher growth curve than Crabtree-positive yeasts such as $S$. cerevisiae. This experiment revealed that $P$. kudriavzeviiKKU20 consumed more sugar (133.1 g) from 0 to $72 \mathrm{~h}$ of incubation than S. cerevisiae, which consumed only $124.6 \mathrm{~g}$ of sugar. Van Urk et al. [51] stated that the sugar consumption rate of a pyruvate decarboxylase-deficient mutant of $S$. cerevisiae is much lower than that of Crabtree-negative yeast strains, indicating that pyruvate decarboxylase could have a strong influence on the glycolytic flux.

Different yeast species might be involved in biomass production. Van Urk, Voll, Scheffers, and Van Dijken [51] reported that S. cerevisiae had low proliferation potential when excessive glucose was present even under aerobic conditions. Wardrop, Liti, Cardinali, and Walker [14] found that Kluyveromyces marxianus provided a larger amount of biomass (seven times greater) than $S$. cerevisiae when cultured in a media solution with excessive glucose. Oxygen acts as the final electron acceptor under aerobic conditions. If the yeasts possess a complete metabolism (e.g., P. kudriavzevii-KKU20 and C. tropicalis-KKU20), then they will produce a large amount of biomass and less alcohol-this condition is called a "Crabtree-negative yeast". In contrast, S. cerevisiae exhibits alcoholic fermentation and produces high amounts of ethanol, i.e., "Crabtree-positive yeast" [48]. This explains why P. kudriavzevii-KKU20 and C. tropicalis-KKU20 produced a larger amount of biomass (more than S. cerevisiae).

The real potential of yeasts as protein sources in ruminant feeding lies in the fact that isolated yeast could increase the amount of biomass produced versus the 11 yeasts and S. cerevisiae. The biomass and cell count data obtained here provide us with an opportunity to create feed for animals from yeast cells that is rich in proteins, essential amino acids, and vitamins. Therefore, the use of different yeast strains may produce interesting results. In addition, cellulase activity increases the possibility of the use of yeast in roughage such as RS, which may add nutritional value.

\section{Conclusions}

Screening and isolating yeasts from rumen fluids resulted in 11 different yeasts. The most valuable yeasts discovered in the rumen fluid of cattle were Pichia kudriavzeviiKKU20, Candida tropicalis-KKU20, and Galactomyces sp.-KKU20, which produce a large amount of biomass and cellulase. The maximum growth of isolated yeast was shown in media containing 25\% sugarcane molasses and 1\% urea with pH 3.5 and 150 rpm shaking. Under these circumstances, P. kudriavzevii-KKU20 has great potential in terms of biomass production, cellulase enzyme activity, and cell number. However, an evaluation of Pichia kudriavzevii-KKU20's ability in terms of fiber improvement and yeast biomass production needs to be carried out to assess the increased nutritive value for ruminant animals.

Author Contributions: Conceptualization, C.S., J.S., M.W., and A.C.; Formal analysis, C.S. and A.C.; Investigation, C.S. and A.C.; Methodology, C.S., J.S. and A.C.; Writing-original draft, C.S.; Writing-review and editing, C.S., J.S., M.W., S.U., V.L., P.C., S.F., and A.C. All authors have read and agreed to the published version of the manuscript.

Funding: The Royal Golden Jubilee Ph.D. Scholarship Program, Thailand Research Fund (TRF Grant No PHD/0132/2560), the Research Program on Toxic Substances, Microorganisms and Feed Additives in Livestock and Aquatic Animals for Food Safety, and the Increase Production Efficiency and Meat Quality of Native Beef and Buffalo Research Group, Khon Kaen University. 
Institutional Review Board Statement: All procedures involving animals in the metabolism studies were approved by the Institutional Animal Care and Use Committee of Khon Kaen University (KKU) (record no. IACUC-KKU 38/62).

Informed Consent Statement: Not applicable: The studies not involving humans.

Data Availability Statement: Data available in a publicly accessible repository.

Acknowledgments: The authors would like to express our sincere thanks to the Tropical Feed Resources Research and Development Center (TROFEC), Department of Animal Science, Faculty of Agriculture, Khon Kaen University, KKU and the Fermentation Research Center for Value Added Agricultural Products (FerVAAP) for the use of research facilities.

Conflicts of Interest: The authors declare no conflict of interest.

\section{References}

1. Campanile, G.; Zicarelli, F.; Vecchio, D.; Pacelli, C.; Neglia, G.; Balestrieri, A.; Di Palo, R.; Infascelli, F. Effects of Saccharomyces cerevisiae on in vivo organic matter digestibility and milk yield in buffalo cows. Livest. Sci. 2008, 114, 358-361. [CrossRef]

2. Marrero, Y.; Castillo, Y.; Ruiz, O.; Burrola, E.; Angulo, C. Feeding of yeast (Candida spp.) improves in vitro ruminal fermentation of fibrous substrates. J. Integr. Agric. 2015, 14, 514-519. [CrossRef]

3. Fonty, G.; Chaucheyras-Durand, F. Effects and modes of action of live yeasts in the rumen. Biologia 2006, 61, 741-750. [CrossRef]

4. Arowolo, M.A.; He, J. Use of probiotics and botanical extracts to improve ruminant production in the tropics. Rev. Anim. Nutr. 2018, 4, 241-249. [CrossRef] [PubMed]

5. Chaucheyras-Durand, F.; Chevaux, E.; Martin, C.; Forano, E. Use of yeast probiotics in ruminants: Effects and mechanisms of action on rumen $\mathrm{pH}$, fibre degradation, and microbiota according to the diet. Biology 2012, 119-152. [CrossRef]

6. Boonnop, K.; Wanapat, M.; Nontaso, N.; Wanapat, S. Enriching nutritive value of cassava root by yeast fermentation. Sci. Agric. 2009, 66, 629-633. [CrossRef]

7. Khampa, S.; Chuelong, S.; Kosonkittiumporn, S.; Khejornsart, P. Manipulation of yeast fermented cassava chip supplementation in dairy heifer raised under tropical condition. Pak. J. Nutr. 2010, 9, 950-954. [CrossRef]

8. Polsit, K.; Chuelong, S.; Siriuthane, T.; Ittarat, S.; Koatedoke, U.; Cherdthong, A.; Khampa, S. Supplementation of cassava and durian hull fermented yeast (Saccharomyces cerevisiae) on rumen fermentation and average daily gain in crossbred native cattle. Pak. J. Nutr. 2011, 10, 1121-1125. [CrossRef]

9. Puramongkon, T.; Thummasaeng, K. Effect of yeast fermented cassava pulp from ethanol production with molasses on feed intake, digestibility and rumen fermentation in beef cattle. Rajabhat Agric. 2017, 16, 26-33.

10. Khampa, S.; Ittharat, S.; Koatdoke, U. Enrichment value of yeast-malate fermented cassava pulp and cassava hay as protein source replace soybean meal in concentrate on rumen ecology in crossbred native cattle. Pak. J. Nutr. 2011, 10, 1126-1131. [CrossRef]

11. Cherdthong, A.; Suntara, C.; Khota, W. Improving nutritive value of ensiled rice straw as influenced by Lactobacillus casei. Khon Kaen Agric. J. 2019, 47, 105-110.

12. Wanapat, M.; Polyorach, S.; Boonnop, K.; Mapato, C.; Cherdthong, A. Effects of treating rice straw with urea or urea and calcium hydroxide upon intake, digestibility, rumen fermentation and milk yield of dairy cows. Livest. Sci. 2009, 125, 238-243. [CrossRef]

13. Foiklang, S.; Upama, P.; Kolyanee, W.; Japanya, R.; Ounpon, P.; Pengsiri, K.; Wanapat, M.; Yammuen-art, S. In vitro gas kinetics and digestibility as influenced by yeast media solution ratios and physical forms of rice straw. Khon Kaen Agric. J. 2017, 45, 74-79.

14. Wardrop, F.; Liti, G.; Cardinali, G.; Walker, G. Physiological responses of Crabtree positive and Crabtree negative yeasts to glucose upshifts in a chemostat. Ann. Microbiol. 2004, 54, 103-114.

15. Verduyn, C.; Zomerdijk, T.P.; van Dijken, J.P.; Scheffers, W.A. Continuous measurement of ethanol production by aerobic yeast suspensions with an enzyme electrode. Appl. Microbiol. Biotechnol. 1984, 19, 181-185. [CrossRef]

16. Sirisan, V.; Pattarajinda, V.; Vichitphan, K.; Leesing, R. Isolation, identification and growth determination of lactic acid-utilizing yeasts from the ruminal fluid of dairy cattle. Lett. Appl. Microbiol. 2013, 57, 102-107. [CrossRef] [PubMed]

17. Suntara, C.; Cherdthong, A.; Uriyapongson, S.; Wanapat, M.; Chanjula, P. Comparison effects of ruminal Crabtree-negative yeasts and Crabtree-positive yeasts for improving ensiled rice straw quality and ruminal digestion using in vitro gas production. $J$. Fungi. 2020, 6, 109. [CrossRef] [PubMed]

18. Sarawan, S.; Mahakhan, P.; Jindamorakot, S.; Vichitphan, K.; Vichitphan, S.; Sawaengkaew, J. Candida konsanensis sp. nov., a new yeast species isolated from Jasminum adenophyllum in Thailand with potentially carboxymethyl cellulase-producing capability. World J. Microbiol. Biotechnol. 2013, 29, 1481-1486. [CrossRef] [PubMed]

19. National Research Council (NRC). Nutrient Requirements of Dairy Cattle, 7th ed.; National Academic Press: Washington, DC, USA, 2001.

20. Sirisan, V. Screening and Identification of Lactic Acid Utilizing Yeasts in the Rumen by Molecular Technique for Increasing Dairy Cattle Performance; Khon Kaen University: Khon Kaen, Thailand, 2013.

21. Kurtzman, C.; Fell, J.; Boekhout, T.; Robert, V. Methods for the Isolation, Maintenance and Identification of Yeasts. The Yeast, A Taxonomic Study; Elsevier: Amsterdam, The Netherlands, 1998; pp. 79-80. 
22. Sarawan, S. Utilization of Agricultural Waste by Using Carboxymethyl Cellulase and Beta-Glucosidase from Yeast for Ethanol Production; Khon Kaen University: Khon Kaen, Thailand, 2013.

23. Johnson, V.W.; Singh, M.; Saini, V.S.; Adhikari, D.K.; Sista, V.; Yadav, N.K. Utilization of molasses for the production of fat by an oleaginous yeast, Rhodotorula glutinis IIP-30. J. Ind. Microbiol. 1995, 14, 1-4. [CrossRef]

24. Mandel, M. Exoglucanase activity by microorganisms. Adv. Chem. 1969, 95, 391-414.

25. Kurtzman, C.P.; Robnett, C.J. Identification and phylogeny of ascomycetous yeasts from analysis of nuclear large subunit (26S) ribosomal DNA partial sequences. Antonie Leeuwenhoek 1998, 73, 331-371. [CrossRef]

26. Darvishi, F.; Moradi, M.; Madzak, C.; Jolivalt, C. Production of laccase by recombinant Yarrowia lipolytica from molasses: Bioprocess development using statistical modeling and increase productivity in shake-flask and bioreactor cultures. Appl. Biochem. Biotechnol. 2017, 181, 1228-1239. [CrossRef]

27. Miller, G. Modified DNS method for reducing sugars. Anal. Chem. 1959, 31, 426-428. [CrossRef]

28. Ghose, T. Measurement of cellulase activities. Pure Appl. Chem. 1987, 59, 257-268. [CrossRef]

29. Luangkriangkrai, A.S.I.C. Determination of ethanol in fermented media by head space the internal standard method in cas chromatography. In Proceedings of the Agricultural Conference, Faculty of Agriculture, Kasetsart University, Bangkok, Thailand, 8-10 December 2011.

30. SAS. User's Guide: Statistic, 12th ed.; Version 6; SAS Institute Inc.: Cary, NC, USA, 1998.

31. Steel, R.G.; Torrie, J.H. Principles and Procedures of Statistics; McGraw-Hill Book Co. Inc.: New York, NY, USA, $1980 ;$ p. 633.

32. Marrero, Y.; Castillo, Y.; Burrola-Barraza, M.E.; Lobaina, T.; Rosa, C.A.; Ruiz, O.; González-Rodríguez, E.; Basso, L.C. Morphological, biochemical and molecular identification of the yeast Levica 25: A potential ruminal microbial additive. Glob. Vet. 2011, 7, 60-65.

33. Marrero, Y.; Burrola-Barraza, M.; Castillo, Y.; Basso, L.C.; Rosa, C.; Ruiz, O.; González-Rodríguez, E. Identification of Levica yeasts as a potential ruminal microbial additive. Czech J. Anim. Sci. 2013, 58, 460-469. [CrossRef]

34. Tefera, T.; Ameha, K.; Biruhtesfa, A. Cassava based foods: Microbial fermentation by single starter culture towards cyanide reduction, protein enhancement and palatability. Int. Food Res. J. 2014, 21, 1751.

35. Paserakung, A.; Pattarajinda, V.; Vichitphan, K.; Froetschel, M. Selection and identification of oleaginous yeast isolated from soil, animal feed and ruminal fluid for use as feed supplement in dairy cattle. Lett. Appl. Microbiol. 2015, 61, 325-332. [CrossRef]

36. Manikandan, K.; Viruthagiri, T. Optimization of $\mathrm{C} / \mathrm{N}$ ratio of the medium and fermentation conditions of ethanol production from tapioca starch using co-culture of Aspergillus niger and Saccharomyces cerevisiae. Int. J. Chem. Technol. Res. 2010, 2, 947-955.

37. Danesi, E.D.G.; Miguel, Â.S.M.; de Oliveira Rangel-Yagui, C.; De Carvalho, J.C.M.; Pessoa, A., Jr. Effect of carbon: Nitrogen ratio $(\mathrm{C}: \mathrm{N})$ and substrate source on glucose-6-phosphate dehydrogenase (G6PDH) production by recombinant Saccharomyces cerevisiae. J. Food Eng. 2006, 75, 96-103. [CrossRef]

38. Sokchea, H.; Thi Hang, P.; Dinh Phung, L.; Duc Ngoan, L.; Thu Hong, T. Effect of time, urea and molasses concentration on Saccharomyces cerevisiae biomass production. J. Vet. Anim. Res. 2018, 1, 104.

39. Khampa, S.; Chaowarat, P.; Singhalert, R.; Wanapat, M. Supplementation of yeast fermented cassava chip as a replacement concentrate on rumen fermentation efficiency and digestibility on nutrients in cattle. Asian-Australas. J. Anim. Sci. 2009, 3, 18-24. [CrossRef]

40. Lynd, L.R.; Weimer, P.J.; Van Zyl, W.H.; Pretorius, I.S. Microbial cellulose utilization: Fundamentals and biotechnology. Microbiol. Mol. Biol. Rev. 2002, 66, 506-577. [CrossRef] [PubMed]

41. Ilmén, M.; Den Haan, R.; Brevnova, E.; McBride, J.; Wiswall, E.; Froehlich, A.; Koivula, A.; Voutilainen, S.P.; Siika-Aho, M.; la Grange, D.C. High level secretion of cellobiohydrolases by Saccharomyces cerevisiae. Biotechnol. Biofuels. 2011, 4, 30. [CrossRef] [PubMed]

42. Du Plessis, L.; Rose, S.H.; van Zyl, W.H. Exploring improved endoglucanase expression in Saccharomyces cerevisiae strains. Appl. Microbiol. Biotechnol. 2010, 86, 1503-1511. [CrossRef]

43. Lund, A. Yeasts and moulds in the bovine rumen. Microbiology 1974, 81, 453-462. [CrossRef]

44. Priji, P.; Unni, K.; Sajith, S.; Benjamin, S. Candida tropicalis BPU1, a novel isolate from the rumen of the Malabari goat, is a dual producer of biosurfactant and polyhydroxybutyrate. Yeast 2013, 30, 103-110. [CrossRef] [PubMed]

45. Shin, E.; Kim, Y.; Lim, W.; Hong, S.; An, C.; Kim, E.; Cho, K.; Choi, B.; An, J.; Kang, J. Phylogenetic analysis of yeast in the rumen contents of cattle based on the $26 \mathrm{~S}$ rDNA sequence. J. Agric. Sci. 2004, 142, 603-611. [CrossRef]

46. Intanoo, M.; Kongkeitkajorn, M.; Pattarajinda, V.; Bernard, J.; Callaway, T.; Suriyasathaporn, W.; Phasuk, Y. Isolation and screening of aflatoxin-detoxifying yeast and bacteria from ruminal fluids to reduce aflatoxin B1 contamination in dairy cattle feed. J. Appl. Microbiol. 2018, 125, 1603-1613. [CrossRef]

47. Pronk, J.T.; Yde Steensma, H.; van Dijken, J.P. Pyruvate metabolism in Saccharomyces cerevisiae. Yeast 1996, 12, 1607-1633. [CrossRef]

48. Dashko, S.; Zhou, N.; Compagno, C.; Piškur, J. Why, when, and how did yeast evolve alcoholic fermentation? FEMS Yeast Res. 2014, 14, 826-832. [CrossRef] [PubMed]

49. Piškur, J.; Compagno, C. Molecular Mechanisms in Yeast Carbon Metabolism, 2014th ed.; Compagno, C., Ed.; Springer: Berlin/Heidelberg, Germany, 2014.

50. Van Dijken, J.P.; Weusthuis, R.A.; Pronk, J.T. Kinetics of growth and sugar consumption in yeasts. Antonie Leeuwenhoek 1993, 63, 343-352. [CrossRef] [PubMed]

51. Van Urk, H.; Voll, W.L.; Scheffers, W.A.; Van Dijken, J.P. Transient-state analysis of metabolic fluxes in Crabtree-positive and Crabtree-negative yeasts. Appl. Environ. Microbiol. 1990, 56, 281-287. [CrossRef] [PubMed] 